\title{
ANALISIS PENILAIAN KESEHATAN BANK MENGGUNAKAN METODE RISK PROFILE, EARNING DAN CAPITAL PADA BPRS
}

\author{
Hulfa Raihani \\ Corresponding Autor's : UIN Imam Bonjol Padang \\ Email : hulfaraihani95@gmail.com \\ Copyright (C) 2022 \\ 13oces.
}

\begin{abstract}
The aim of this research to was find out the health level Islamic Rural Banks in West Sumatra Province for the 2014-2018 period using the Risk Profile, Earning, and Capital methods. This research used a quantitative approach that was supported by the use of descriptive statistical analysis. The results show that this study can be concluded that during 2014-2018 based on several financial ratios that exist in the RGEC method, namely Non Performing Financing (NPF), Financing to Deposit Ratio (FDR), Return on Asset (ROA), Return on Equity (ROE), Beban Operasional Pendapatan Operasiona (BOPO) and Capital Adequacy Ratio (CAR) at Islamic Rural Banks, which consists of PT BPRS Ampek Angkek Canduang, PT BPRS Carana Kiat Andalas, and PT BPRS Haji Miskin as a whole are ranked less healthy (PK-4), with a composite value of $56.66 \%$.
\end{abstract}

Keywords: Islamic Rural Banks, Risk Profile, Earning, Capital

\begin{abstract}
Abstrak: Penelitian ini bertujuan untuk mengetahui tingkat kesehatan BPRS di Provinsi Sumatera Barat periode 2014-2018 dengan menggunakan Metode Risk Profile, Earning, dan Capital. Penelitian ini menggunakan pendekatan kuantitatif yang didukung dengan penggunaan analisis statistik deskriptif. Hasil penelitian menunjukkan bahwa selama tahun 2014-2018 berdasarkan beberapa rasio keuangan yang ada pada metode RGEC yaitu Non Performing Financing (NPF), Financing to Deposit Ratio (FDR), Return on Asset (ROA), Return terhadap Equity (ROE), Beban Operasional Pendapatan Operasiona (BOPO) dan Capital Adequacy Ratio (CAR) pada Bank Perkreditan Rakyat Syariah yang terdiri dari PT BPRS Ampek Angkek Canduang, PT BPRS Carana Kiat Andalas, dan PT BPRS Haji Miskin secara keseluruhan diperingkatkan kurang sehat (PK-4), dengan nilai komposit 56,66\%.
\end{abstract}

Kata Kunci: Bank Pembiayaan Rakyat Syariah, Risk Profile, Earning, Capital

\section{PENDAHULUAN}

Dalam pandangan Islam,

aktivitas keuangan dalam perbankan merupakan suatu wahana bagi masyarakat untuk membawanya kepada pelaksanaan ajaran Al-Quran yaitu prinsip At-Ta'awun (saling membantu dan bekerja sama diantara anggota masyarakat untuk kebaikan) dan prinsip menghindari Al-Ikhtinaz 
(menahan dan membiarkan dana menganggur dan tidak digunakan untuk aktivitas atau transaksi yang lebih bermanfaat).

Bank memegang peranan penting dalam kehidupan di masyarakat karena bank merupa kan sektor yang menggerakkan roda perekonomian dengan menghubung kan antara surplus di sektor keuangan dan defisit disektor rill (Putri \& Marsiwi, 2018). Bank yang memiliki peranan yang sangat penting dalam masyarakat, bukan hanya sebagai sumber dana bagi pihak yang kekurangan dana tetapi juga sebagai tempat penyimpanan uang bagi pihak yang kelebihan dana, dimana bank memiliki fungsi-fungsi lain yang semakin maju, yaitu telah mendorong bank untuk menciptakan produk dan layanan untuk kepuasan dan kemudahan masyarakat, seperti menyediakan mekanisme, alat pembayaran yang lebih efisien, dan memberikan pelayanan penyimpanan barang-barang berharga serta penawaran jasa lainnya dimana perbankan dalam menjalankan peranannya membutuhkan kepercaya an karena salah satu modal pokok perbankan adalah kepercayaan (Suhendro \& Wijayanti, 2016).

Menjadi lembaga keuangan yang berkompeten bank harus mampu melakukan fungsinya sesuai dengan aturan yang ada. Kompetensi ini sangat berguna untuk meningkatkan tingkat kepercayaan masyarakat terhadap sektor perbankan itu sendiri. Guna membangun hubungan yang baik dengan masyarakat, bank harus memiliki tingkat kesehatan bank yang baik. Penilaian ini dapat dijadikan salah satu pemicu meningkatnya tingkat kepercayaan masyarakat kepada bank (Oktaviani, 2018).

Bank syariah lahir sebagai salah satu solusi alternatif terhadap persoalan pertentangan antara bunga bank dengan riba. Bank syariah yang memiliki filosofi utama kemitraan dan kebersamaan (sharing) dalam profit dan risk diharapkan mampu mengakomodasi kebutuhan masyarakat terhadap layanan jasa perbankan yang sesuai dengan prinsip syariah. Dalam sistem operasionalnya, perbankan syariah pada dasarnya memiliki comparative advantage yang tidak dapat tersaingi dengan sistem konvensional, yaitu digunakannya standar moral Islami dalam kegiatan usahanya, dimana azaz keadilan dan kemanfaatan bagi seluruh umat mampu mendorong terciptanya sinergi yang sangat bermanfaat bagi bank dan nasabah nya. Selain itu, penerapan prinsip bagi hasil juga sebagai salah satu prinsip pokok dalam kegiatan perbankan syariah yang akan menumbuhkan rasa tanggungjawab pada masing-masing pihak, baik bank maupun debiturnya (Muhammad, 2005).

Perkembangan bank syariah dari tahun ke tahun patut dibanggakan dan dapat dikatakan sebagai salah satu sektor yang berkembang pesat di Indonesia. Perkembangan jumlah 
lembaga keuangan syariah di Indonesia Bank Pembiayaan Rakyat Syariah yang terdiri dari Bank Umum Syariah

(BPRS) ditunjukkan pada tabel berikut : (BUS), Unit Usaha Syariah (UUS), dan

Tabel 1 Perkembangan Perbankan Syariah Berdasarkan Jumlah Bank di Indonesia

\begin{tabular}{ccccccc}
\hline \multirow{2}{*}{ Indikator } & 2014 & 2015 & 2016 & 2017 & 2018 & 2019 \\
\cline { 2 - 7 } & 12 & 12 & 13 & 13 & 14 & 14 \\
\hline BUS & 22 & 22 & 21 & 21 & 20 & 20 \\
\hline UUS & 163 & 163 & 166 & 167 & 167 & 164 \\
\hline BPRS & Sumber : Statistik Perbankan Syariah, OJK 2019
\end{tabular}

Berdasarkan

tabel

perkembangan perbankan syariah pada tahun 2014 jumlah Bank Umum Syariah (BUS) beroperasi sebanyak 12 bank, 22 Unit Usaha Syariah (UUS), dan 163 Bank Pembiayaan Rakyat Syariah (BPRS). Sehingga pada tahun 2018, jumlah Bank Umum Syariah beroperasi sebanyak 14 bank, diikuti oleh 20 Unit Usaha Syariah, dan 167 Bank Pembiayaan Rakyat Syariah.

\section{KAJIAN TEORI}

\section{Bank Pembiayaan Rakyat Syariah}

Bank adalah badan usaha yang menghimpun dana dari masyarakat dalam bentuk simpanan dan menyalurkannya dalam bentuk kredit atau bentuk lainnya dalam rangka meningkatkan taraf hidup rakyat (Hasan, 2009). Pembiayaan ialah penyediaan uang/tagihan yang berdasarkan pada persetujuan atau kesepakatan antara bank dengan pihak lain yang mewajibkan pihak yang dibiayai untuk mengembalikan uang/tagihan tersebut setelah jangka 30 | Analisis Penilaian Kesehatan Bank Menggunakan Metode Risk Profile.......
1 waktu tertentu dengan imbalan/bagi hasil . Jadi, Bank Pembiayaan Rakyat Syariah (BPRS) adalah bank yang melaksanakan kegiatan usaha berdasarkan prinsip syariah yang dalam kegiatannya tidak memberikan jasa dalam lalu lintas pembayaran (Darsono, 2017).

\section{Kesehatan Bank}

Kesehatan suatu bank dapat diartikan sebagai kemampuan suatu bank untuk melakukan kegiatan operasional perbankan secara normal dan mampu memenuhi semua kewajibannya dengan baik dengan cara-cara yang sesuai dengan peraturan perbankan yang berlaku (Budisantoso \& Nuritomo, 2015). Ukuran untuk melakukan penilaian kesehatan bank telah ditentukan oleh Bank Indonesia. Kepada Bank-bank diharuskan membuat laporan baik yang bersifat rutin atau secara berkala mengenai seluruh aktivitasnya dalam suatu periode tertentu (Kasmir, 2003).

Kesehatan atau kondisi keuangan bank atau non keuangan 
bank merupakan kepentingan semua pihak terkait, baik pemilik, manajemen bank, bank pemerintah dan pengguna jasa bank. dengan diketahui kondisi suatu bank dapat digunakan oleh pihakpihak tersebut untuk mengevaluasi kinerja bank dalam menerapkan prinsip kehati-hatian, kepatuhan terhadap ketentuan yang berlaku dan manajemen resiko (Veithrizal, 2007). Kesehatan suatu bank dapat diartikan sebagai kemampuan suatu bank untuk melakukan kegiatan operasional perbankan secara normal dan mampu memenuhi semua kewajibannya dengan baik dengan cara-cara yang sesuai dengan peraturan perbankan yang berlaku (Budisantoso \& Nuritomo, 2015) Ukuran untuk melakukan penilaian kesehatan bank telah ditentukan oleh Bank Indonesia. Kepada Bank-bank diharuskan membuat laporan baik yang bersifat rutin atau secara berkala mengenai seluruh aktivitasnya dalam suatu periode tertentu. Semakin meningkatnya profil risiko dan kompleksitas usaha bank harus meng identifikasi permasalahan yang akan timbul dari operasional bank. Dimana setiap tahun penilaian kesehatan bank harus dilakukan untuk mengetahui apakah bank tersebut ada mengalami peningkatan atau penurunan. Jika bank yang kesehatannya terus meningkat berarti manajemennya mampu mem pertahankan kinerja, akan tetapi jika bank yang terus menerus tidak sehat, berarti bank harus memperbaiki kinerja manajemen dan mesti mendapatkan pengarahan atau sanksi dari Bank Indonesia sebagai pengawas dan pembina bank.

Penilaian Tingkat Kesehatan Bank Dengan Metode Risk Profile, Earning, dan Capital

Cakupan penilaian tingkat kesehatan bank yang digunakan adalah penilaian terhadap faktor-faktor : Profil risiko (Risk Profile), Earnings (Rentabilitas), dan Capital (Permodalan). Penjelasan faktor penilaian tingkat kesehatan bank adalah sebagai berikut: Risk Profile (Profil Risiko) Rasio keuangan penilaian rentabilitas dalam penilaian ini menggunakan rasio ROA, ROE dan BOPO. Rasio ini yang sering disebut rasio efisiensi yang digunakan untuk mengukur kemampuan manajemen bank dalam mengendalikan biaya operasional terhadap pendapatan operasional. Dimana semakin kecil rasio ini berarti semakin efisien biaya operasional yang dikeluarkan bank yang bersangkutan sehingga kemungkinan laba bank akan semakin meningkat (Dendawijaya, 2009).

Capital (permodalan) Dalam rangka menjamin dan memelihara tingkat kesehatan perbankan syariah, bank yang menjalankan kegiatan usaha berdasarkan prinsip syariah diwajibkan untuk memenuhi rasio kewajiban penyediaan modal minimum KPMM atau Capital Adequacy Ratio (CAR) sebagaimana ditetapkan dalam ketentuan Bank Indonesia. Ketentuan dalam Pasal 11 Undang-Undang No. 21 Tahun 2008 menegaskan, bahwa 
besarnya modal disetor mnimum untuk mendirikan bank syariah ditetapkan dalam peraturan Bank Indonesia (Indonesia, 2016)

\section{METODOLOGI PENELITIAN Jenis Penelitian}

Pendekatan kuantitatif dalam penelitian ini didukung dengan penggunaan analisis statistik deskriptif. Teknik analisis statistik deskriptif adalah teknik analisis statistik yang memberikan informasi hanya mengenai data yang diamati dengan cara mendeskripsikan data yang telah terkumpul sebagaimana adanya serta tanpa bermaksud menarik kesimpulan yang digeneralisasikan terhadap populasi, dalam hal ini antara lain penyajian data melalui tabel atau grafik. Perhitungan data dengan menggunakan frekuensi dan penggunaan persentase. Dalam penelitian ini penulis menggunakan persentase dalam menentu kan penilaian peringkat kesehatan BPRS Sumatra Barat Periode 2014-2018

\section{Populasi dan Sampel}

Populasi dalam penelitian ini adalah kelompok Bank Pembiayaan Rakyat Syariah di Sumatera Barat yang terdiri dari 7 Bank yang dibawah pengawasan Otoritas Jasa Keuangan, yang terdiri dari : PT BPRS Carana Kiat Andalas (Kab. Agam), PT BPRS Ampek Angkek Canduang (Kab. Agam), PT BPRS Haji Miskin (Kab. Tanah Datar), PT BPRS Barakah Nawaitul Ikhlas (Kota Solok), PT BPRS Al-Makmur (Kab.
Limah Puluh Kota), PT BPRS Mentari Pasaman Saiyo (Kab. Pasaman Barat), PT BPRS Gajah Tongga Koto Piliang (Kota Sawah Lunto).

\section{Teknik Pengumpulan Data}

Teknik pengumpulan data yang digunakan adalah metode dokumentasi. Dokumentasi adalah metode pengumpulan data dengan mengumpul kan semua informasi mengenai objek penelitian. Objek penelitian yang dimaksud adalah laporan keuangan publikasi tahunan Bank Pembiayaan Rakyat Syariah (BPRS) di Sumatera Barat periode 2014-2018.

\section{Metode Analisis Data dan Pengolahan Data}

Rasio yang digunakan sebagai variabel indikator penilaian kesehatan sebagai berikut:

\section{Risk Profile (Profil Risiko)}

Dalam penelitian ini mengukur faktor risk profile dengan menggunakan dua indikator yaitu faktor risiko pembiayaan dengan menggunakan rumus NPF dan risiko likuiditas dengan rumus FDR. Risiko Pembiayaan Resiko pembiayaan ditunjukkan dengan besaran Non Performing Financing (NPF) merupakan persentase jumlah pembiayaan bermasalah (dengan kriteria kurang lancar, diragukan, dan macet) terhadap total pembiayaan yang disalurkan bank. Rumus untuk menghitung rasio Non Performing Financing (NPF):

$$
N P F=\frac{\text { Pembiayaan Bermasalah }}{\text { Total Pembiayaan }} \times 100
$$


Tabel 2

Matrik Kriteria Penetapan Peringkat Komponen Risiko Pembiayaan

\begin{tabular}{ccc}
\hline Peringkat & Ketentuan & Kriteria \\
\hline 1 & Sangat Sehat & NPF $<7 \%$ \\
\hline 2 & Sehat & $7 \%<\mathrm{NPF} \leq 10 \%$ \\
\hline 3 & Cukup Sehat & $10 \%<\mathrm{NPF} \leq 13 \%$ \\
\hline 4 & Kurang Sehat & $13 \%<\mathrm{NPF} \leq 16 \%$ \\
\hline 5 & Tidak Sehat & $\mathrm{NPF}>16 \%$
\end{tabular}

Sumber : Surat Edaran Bank Indonesia No. 13/24/DPNP Tahun 2011

\section{Risiko Likuiditas}

Risiko likuiditas adalah risiko akibat ketidakmampuan bank untuk memenuhi kewajiban yang telah jatuh tempo dari sumber pendanaan arus kas, dan dari aset likuid berkualitas tinggi yang diagunkan tanpa mengganggu aktivitas dan kondisi keuangan bank. Rumus untuk menghitung Risiko likuiditas dihitung dengan menggunakan rasio Financing to Deposit Ratio (FDR) :

$$
F D R=\frac{\text { Total Pembiayaan }}{\text { Dana Pihak Ketiga }} \times 100 \%
$$

Tabel 3

Matrik Kriteria Penetapan Peringkat Komponen Risiko Likuiditas

\begin{tabular}{ccc}
\hline Peringkat & Ketentuan & Kriteria \\
\hline 1 & Sangat Sehat & $70 \% \leq$ FDR $\leq 85 \%$ \\
\hline 2 & Sehat & $60 \% \leq$ FDR $\leq 70 \%$ \\
\hline 3 & Cukup Sehat & $85 \% \leq$ FDR $\leq 100 \%$ \\
\hline 4 & Kurang Sehat & $100 \% \leq$ FDR $\leq 120 \%$ \\
\hline 5 & Tidak Sehat & FDR $>120 \%$ \\
\hline \multicolumn{2}{l}{ Sumber $:$ Surat Edaran Bank Indonesia No. $13 / 24 /$ DPNP Tahun 2011}
\end{tabular}

\section{Earnings (Rentabilitas)}

Penilaian terhadap faktor earnings didasarkan pada tiga rasio:

Return On Assets (ROA)

ROA digunakan untuk mengukur kemampuan mana jemen bank dalam memperoleh keuntungan (laba bersih sebelum pajak). Besarnya ROA dapat dihitung dengan menggunakan rumus sebagai berikut :

$$
R O A=\frac{\text { Laba Sebelum Pajak }}{\text { Rata }- \text { rata Total Aset }} \times 100 \%
$$

Tabel 4

Matrik Kriteria Penetapan Peringkat Komponen Penilaian ROA

\begin{tabular}{ccc}
\hline Peringkat & Ketentuan & Kriteria \\
\hline 1 & Sangat Sehat & ROA $>1.45 \%$ \\
\hline 2 & Sehat & $1.21 \%<$ ROA $\leq 1.45 \%$ \\
\hline 3 & Cukup Sehat & $0.99 \%<$ ROA $\leq 1.21 \%$ \\
\hline 4 & Kurang Sehat & $0.76 \%<$ ROA $\leq 0.99 \%$ \\
\hline 5 & Tidak Sehat & ROA $\leq 0.76 \%$ \\
\hline \multicolumn{2}{c}{ Sumber $:$ Surat Edaran Bank Indonesia No. $13 / 24 /$ DPNP Tahun 2011}
\end{tabular}


Beban Operasional Terhadap

Pendapatan Operasional

Rasio BOPO digunakan untuk mengukur tingkat efisiensi dan kemampuan manajemen bank dalam mengendalikan biaya operasional terhadap pendapatan operasional.
Rasio ini merupakan perbandingan Biaya Operasional dengan Pendapatan Operasional. Besarnya nilai BOPO dapat dihitung dengan rumus :

$B O P O=\frac{\text { Beban Operasional }}{\text { Pendapatan Operasional }} \times 100 \%$

Tabel 6

Matrik Kriteria Penetapan Peringkat Komponen Penilaian BOPO

\begin{tabular}{ccc}
\hline Peringkat & Ketentuan & Kriteria \\
\hline 1 & Sangat Sehat & BOPO $<83 \%$ \\
\hline 2 & Sehat & $83 \%<$ BOPO $\leq 85 \%$ \\
\hline 3 & Cukup Sehat & $85 \%<$ BOPO $\leq 87 \%$ \\
\hline 4 & Kurang Sehat & $87 \%<$ BOPO $\leq 89 \%$ \\
\hline 5 & Tidak Sehat & BOPO $>100 \%$ \\
\hline
\end{tabular}

Sumber : Surat Edaran Bank Indonesia No. 13/24/DPNP 2011

Capital (Permodalan)

CAR adalah rasio kinerja bank untuk mengukur kecukupan modal yang dimiliki bank guna menutupi kemungkinan kegagalan dalam pemberian pembiayaan. Rasio ini menggunakan rasio Capital Adequacy Ratio (CAR) yang dapat dirumuskan sebagai

Tabel 7

Matrik Kriteria Penetapan Peringkat Komponen Penilaian CAR

\begin{tabular}{ccc}
\hline Peringkat & Ketentuan & Kriteria \\
\hline 1 & Sangat Sehat & CAR $\geq 11 \%$ \\
\hline 2 & Sehat & $9.5 \% \leq$ CAR $<11 \%$ \\
\hline 3 & Cukup Sehat & $8 \% \leq$ CAR $<9.5 \%$ \\
\hline 4 & Kurang Sehat & $6.5 \% \leq$ CAR $<8 \%$ \\
\hline 5 & Tidak Sehat & CAR $<6.5 \%$ \\
\hline \multicolumn{2}{l}{ Sumber $:$ Surat Edaran Bank Indonesia No. $13 / 24 /$ DPNP 2011}
\end{tabular}

\section{HASIL DAN PEMBAHASAN}

Perhitungan analisis rasio RGEC periode 2014 sampai 2018 pada BPRS di Sumatera Barat, maka dapat diakumulasikan Peringkat Komposit kesehatan selama 5 tahun di tabel 8. Tingkat kesehatan BPRS yang terdiri dari PT BPRS Ampek Angkek Canduang, PT BPRS Carana Kiat Andalas dan PT BPRS Haji Miskin jika ditinjau dari 
indikator NPF dimana pada tahun 2014-2016 dan tahun 2018 memperoleh predikat tidak sehat yaitu pada tahun 2014 sebesar 17,47\%, 2015 sebesar 25,15\%, 2016 sebesar 20,57\%, dan tahun 2018 sebesar 17,34\% ini berarti bahwa bank memiliki aktiva produktif dengan tingkat pengembalian yang sangat rendah, dana yang disalurkan oleh bank dalam bentuk pembiayaan memiliki kemampuan pengembalian yang sangat rendah sehingga mengindikasikan bahwa nasabah yang masuk dalam kategori bermasalah sangat tinggi. Kemudian pada tahun 2017 memperoleh predikat kurang sehat sebesar $14,60 \%$ ini berarti bahwa bank memiliki aktiva produktif dengan tingkat pengembalian yang rendah.

Jadi, dapat disimpulkan bahwa kesehatan Bank Pembiayaan Rakyat Syariah di Sumatera Barat periode 2014-2018 jika ditinjau dari indikator NPF (Non Performing Financing) berada pada predikat tidak sehat yaitu sebesar $19,03 \%$ ini berarti bahwa bank memiliki aktiva produktif dengan tingkat pengembalian yang sangat rendah, dana yang disalurkan oleh bank dalam bentuk pembiayaan memiliki kemampuan pengembalian yang sangat rendah sehingga mengindikasikan bahwa nasabah yang masuk dalam kategori bermasalah sangat tinggi.

Tabel 8

Kesehatan Bank Pembiayaan Rakyat Syariah Berdasarkan Rasio NPF

\begin{tabular}{|c|c|c|}
\hline Tahun & BPRS & NPF \\
\hline \multirow{4}{*}{2014} & PT BPRS Ampek Angkek Canduang & $5,67 \%$ \\
\hline & PT BPRS Carana Kiat Andalas & $45,37 \%$ \\
\hline & PT Haji Miskin & $1,39 \%$ \\
\hline & Rata-rata & $17,47 \%$ \\
\hline \multirow[t]{4}{*}{2015} & PT BPRS Ampek Angkek Canduang & $19,52 \%$ \\
\hline & PT BPRS Carana Kiat Andalas & $54,23 \%$ \\
\hline & PT Haji Miskin & $1,72 \%$ \\
\hline & Rata-rata & $25,15 \%$ \\
\hline \multirow[t]{4}{*}{2016} & PT BPRS Ampek Angkek Canduang & $18,38 \%$ \\
\hline & PT BPRS Carana Kiat Andalas & $40,72 \%$ \\
\hline & PT Haji Miskin & $2,63 \%$ \\
\hline & Rata-rata & $20,57 \%$ \\
\hline \multirow[t]{4}{*}{2017} & PT BPRS Ampek Angkek Canduang & $16,81 \%$ \\
\hline & PT BPRS Carana Kiat Andalas & $22,67 \%$ \\
\hline & PT Haji Miskin & $4,32 \%$ \\
\hline & Rata-rata & $14,60 \%$ \\
\hline \multirow[t]{5}{*}{2018} & PT BPRS Ampek Angkek Canduang & $19,37 \%$ \\
\hline & PT BPRS Carana Kiat Andalas & $28,03 \%$ \\
\hline & PT Haji Miskin & $4,63 \%$ \\
\hline & Rata-rata & $17,34 \%$ \\
\hline & JUMLAH & $19,03 \%$ \\
\hline
\end{tabular}


Tingkat kesehatan BPRS yang terdiri dari PT BPRS Ampek Angkek Canduang, PT BPRS Carana Kiat Andalas dan PT BPRS Haji Miskin jika ditinjau dari indikator NPF dimana pada tahun 2014-2016 dan tahun 2018 memperoleh predikat tidak sehat yaitu pada tahun 2014 sebesar 17,47\%, 2015 sebesar 25,15\%, 2016 sebesar 20,57\%, dan tahun 2018 sebesar 17,34\% bahwa bank memiliki aktiva produktif dengan tingkat pengembalian yang sangat rendah, dengan kata lain dapat juga dijelaskan bahwa dana yang disalurkan oleh bank dalam bentuk pembiayaan memiliki kemampuan pengembalian yang sangat rendah sehingga mengindikasikan bahwa nasabah yang masuk dalam kategori bermasalah sangat tinggi. Kemudian pada tahun
2017 memperoleh predikat kurang sehat sebesar $14,60 \%$ ini berarti bahwa bank memiliki aktiva produktif dengan tingkat pengembalian yang rendah.

Jadi, dapat disimpulkan bahwa kesehatan Bank Pembiayaan Rakyat Syariah di Sumatera Barat periode 2014-2018 jika ditinjau dari indikator NPF berada pada predikat tidak sehat yaitu sebesar 19,03\% ini berarti bahwa bank memiliki aktiva produktif dengan tingkat pengembalian yang sangat rendah, dengan kata lain dapat juga dijelaskan bahwa dana yang disalurkan oleh bank dalam bentuk pembiayaan memiliki kemampuan pengembalian yang sangat rendah sehingga mengindikasikan bahwa nasabah yang masuk dalam kategori bermasalah sangat tinggi

Tabel 9

Kesehatan Bank Pembiayaan Rakyat Syariah Berdasarkan Rasio FDR

\begin{tabular}{|c|c|c|}
\hline Tahun & BPRS & FDR \\
\hline \multirow[t]{4}{*}{2014} & PT BPRS Ampek Angkek Canduang & $220,40 \%$ \\
\hline & PT BPRS Carana Kiat Andalas & $258,40 \%$ \\
\hline & PT Haji Miskin & $338,90 \%$ \\
\hline & Rata-rata & $272,56 \%$ \\
\hline \multirow[t]{4}{*}{2015} & PT BPRS Ampek Angkek Canduang & $132,70 \%$ \\
\hline & PT BPRS Carana Kiat Andalas & $204,93 \%$ \\
\hline & PT Haji Miskin & $276,77 \%$ \\
\hline & Rata-rata & $204,80 \%$ \\
\hline \multirow[t]{4}{*}{2016} & PT BPRS Ampek Angkek Canduang & $143,50 \%$ \\
\hline & PT BPRS Carana Kiat Andalas & $244,90 \%$ \\
\hline & PT Haji Miskin & $276,10 \%$ \\
\hline & Rata-rata & $221,50 \%$ \\
\hline \multirow[t]{4}{*}{2017} & PT BPRS Ampek Angkek Canduang & $144,80 \%$ \\
\hline & PT BPRS Carana Kiat Andalas & $303,20 \%$ \\
\hline & PT Haji Miskin & $109,70 \%$ \\
\hline & Rata-rata & $185,90 \%$ \\
\hline \multirow[t]{5}{*}{2018} & PT BPRS Ampek Angkek Canduang & $142,20 \%$ \\
\hline & PT BPRS Carana Kiat Andalas & $299,40 \%$ \\
\hline & PT Haji Miskin & $120,20 \%$ \\
\hline & Rata-rata & $187,26 \%$ \\
\hline & JUMLAH & $214,40 \%$ \\
\hline
\end{tabular}


Tingkat kesehatan BPRS yang terdiri dari PT BPRS Ampek Angkek Canduang, PT BPRS Carana Kiat Andalas dan PT BPRS Haji Miskin jika ditinjau dari indikator FDR pada tahun 2014-2018 memperoleh predikat tidak sehat yaitu pada tahun 2014 sebesar 272,56\%, 2015 sebesar 204,80\%, 2016 sebesar 221,50\%, 2017 sebesar 185,90\% dan tahun 2018 sebesar $187,26 \%$ ini berarti bahwa ini berarti bahwa DPK sangat tidak stabil yang cenderung menurun secara permanen atau trend pertumbuhan negatif yang sangat signifikan.

Jadi, dapat disimpulkan bahwa kesehatan Bank Pembiayaan Rakyat Syariah di Sumatera Barat periode 2014-2018 jika ditinjau dari indikator FDR (Financing To Deposit Ratio) berada pada predikat tidak sehat yaitu sebesar 214,40\% ini berarti bahwa ini berarti bahwa DPK sangat tidak stabil yang cenderung menurun secara permanen atau trend pertumbuhan negatif yang sangat signifikan.

Tabel 10

Kesehatan Bank Pembiayaan Rakyat Syariah Berdasarkan Rasio ROA

\begin{tabular}{|c|c|c|}
\hline Tahun & BPRS & ROA \\
\hline \multirow[t]{4}{*}{2014} & PT BPRS Ampek Angkek Canduang & $1,50 \%$ \\
\hline & PT BPRS Carana Kiat Andalas & $-6,98 \%$ \\
\hline & PT Haji Miskin & $2,75 \%$ \\
\hline & Rata-rata & $-0,91 \%$ \\
\hline \multirow[t]{4}{*}{2015} & PT BPRS Ampek Angkek Canduang & $1,03 \%$ \\
\hline & PT BPRS Carana Kiat Andalas & $-3,52 \%$ \\
\hline & PT Haji Miskin & $2,10 \%$ \\
\hline & Rata-rata & $-0,13 \%$ \\
\hline \multirow[t]{4}{*}{2016} & PT BPRS Ampek Angkek Canduang & $1,03 \%$ \\
\hline & PT BPRS Carana Kiat Andalas & $-0,71 \%$ \\
\hline & PT Haji Miskin & $2,43 \%$ \\
\hline & Rata-rata & $0,91 \%$ \\
\hline \multirow[t]{4}{*}{2017} & PT BPRS Ampek Angkek Canduang & $1,56 \%$ \\
\hline & PT BPRS Carana Kiat Andalas & $-0,75 \%$ \\
\hline & PT Haji Miskin & $2,74 \%$ \\
\hline & Rata-rata & $1,18 \%$ \\
\hline \multirow[t]{5}{*}{2018} & PT BPRS Ampek Angkek Canduang & $1,38 \%$ \\
\hline & PT BPRS Carana Kiat Andalas & $-0,91 \%$ \\
\hline & PT Haji Miskin & $2,84 \%$ \\
\hline & Rata-rata & $1,10 \%$ \\
\hline & JUMLAH & $-0,24 \%$ \\
\hline
\end{tabular}

Tingkat kesehatan BPRS yang terdiri dari PT BPRS Ampek Angkek Canduang, PT BPRS Carana Kiat
Andalas dan PT BPRS Haji Miskin jika ditinjau dari indikator ROA pada tahun 2014 dan 2015 memperoleh predikat 
tidak sehat yaitu sebesar $-0,91 \%$ dan $0,13 \%$ ini berarti bahwa sedang mengalami kerugian. Kemudian pada tahun 2016 memperoleh predikat kurang sehat yaitu sebesar 0,91\% yang meningkat dari tahun 2014 dan 2015 ini berarti bahwa perolehan laba bank rendah atau cenderung mengalami kerugian. Selanjutnya tahun 2017 dan 2018 memperoleh predikat cukup sehat yaitu sebesar 1,18\% dan 1,10\% ini berati bahwa perolehan labanya cukup tinggi. Jadi, dapat disimpulkan bahwa kesehatan Bank Pembiayaan Rakyat Syariah di Sumatera Barat periode 2014-2018 jika ditinjau dari indikator ROA (Return On Asset) berada pada predikat tidak sehat yaitu sebesar $0,24 \%$ ini berarti bahwa sedang mengalami kerugian

Tabel 11

Kesehatan Bank Pembiayaan Rakyat Syariah Berdasarkan Rasio ROE

\begin{tabular}{|c|c|c|}
\hline Tahun & BPRS & ROE \\
\hline \multirow[t]{4}{*}{2014} & PT BPRS Ampek Angkek Canduang & $12,80 \%$ \\
\hline & PT BPRS Carana Kiat Andalas & $-245,19 \%$ \\
\hline & PT Haji Miskin & $14,92 \%$ \\
\hline & Rata-rata & $-72,49$ \\
\hline \multirow[t]{4}{*}{2015} & PT BPRS Ampek Angkek Canduang & $9,01 \%$ \\
\hline & PT BPRS Carana Kiat Andalas & $-100,14 \%$ \\
\hline & PT Haji Miskin & $13,26 \%$ \\
\hline & Rata-rata & $-25,95 \%$ \\
\hline \multirow[t]{4}{*}{2016} & PT BPRS Ampek Angkek Canduang & $11,33 \%$ \\
\hline & PT BPRS Carana Kiat Andalas & $-7,66 \%$ \\
\hline & PT Haji Miskin & $14,96 \%$ \\
\hline & Rata-rata & $6,21 \%$ \\
\hline \multirow[t]{4}{*}{2017} & PT BPRS Ampek Angkek Canduang & $13,39 \%$ \\
\hline & PT BPRS Carana Kiat Andalas & $-12,13 \%$ \\
\hline & PT Haji Miskin & $16,12 \%$ \\
\hline & Rata-rata & $5,79 \%$ \\
\hline \multirow[t]{5}{*}{2018} & PT BPRS Ampek Angkek Canduang & $10,38 \%$ \\
\hline & PT BPRS Carana Kiat Andalas & $-6,06 \%$ \\
\hline & PT Haji Miskin & $17,39 \%$ \\
\hline & Rata-rata & $7,23 \%$ \\
\hline & JUMLAH & $-15,84 \%$ \\
\hline
\end{tabular}

Tingkat kesehatan BPRS yang ditinjau dari indikator ROE pada tahun terdiri dari PT BPRS Ampek Angkek 2014 dan 2015 memperoleh predikat Canduang, PT BPRS Carana Kiat kurang sehat yaitu sebesar-72,49\% dan Andalas dan PT BPRS Haji Miskin jika -25,95\% ini berarti bahwa perolehan 
laba bank rendah atau cenderung mengalami kerugian. Kemudian tahun 2016-2018 memperoleh predikat cukup sehat yaitu sebesar tahun 2016 sebesar 6,21\%, tahun 2017 sebesar 5,79\%, dan tahun 2018 sebesar 7,23 ini berati bahwa perolehan labanya cukup tinggi. Jadi, dapat disimpulkan bahwa kesehatan Bank Pembiayaan Rakyat Syariah di Sumatera Barat periode 2014-2018 jika ditinjau dari indikator ROE (Return On Equity) berada pada predikat tidak sehat yaitu sebesar $15,84 \%$.

Tabel 12

Kesehatan Bank Pembiayaan Rakyat Syariah Berdasarkan Rasio BOPO

\begin{tabular}{|c|c|c|}
\hline Tahun & BPRS & BOPO \\
\hline \multirow[t]{4}{*}{2014} & PT BPRS Ampek Angkek Canduang & $56,54 \%$ \\
\hline & PT BPRS Carana Kiat Andalas & $113,83 \%$ \\
\hline & PT Haji Miskin & $45,16 \%$ \\
\hline & Rata-rata & $71,84 \%$ \\
\hline \multirow[t]{4}{*}{2015} & PT BPRS Ampek Angkek Canduang & $58,47 \%$ \\
\hline & PT BPRS Carana Kiat Andalas & $113,83 \%$ \\
\hline & PT Haji Miskin & $48,52 \%$ \\
\hline & Rata-rata & $73,60 \%$ \\
\hline \multirow[t]{4}{*}{2016} & PT BPRS Ampek Angkek Canduang & $51,86 \%$ \\
\hline & PT BPRS Carana Kiat Andalas & $104,02 \%$ \\
\hline & PT Haji Miskin & $49,96 \%$ \\
\hline & Rata-rata & $68,61 \%$ \\
\hline \multirow[t]{4}{*}{2017} & PT BPRS Ampek Angkek Canduang & $67,45 \%$ \\
\hline & PT BPRS Carana Kiat Andalas & $93,82 \%$ \\
\hline & PT Haji Miskin & $51,70 \%$ \\
\hline & Rata-rata & $70,99 \%$ \\
\hline \multirow[t]{5}{*}{2018} & PT BPRS Ampek Angkek Canduang & $72,31 \%$ \\
\hline & PT BPRS Carana Kiat Andalas & $83,94 \%$ \\
\hline & PT Haji Miskin & $49,22 \%$ \\
\hline & Rata-rata & $68,49 \%$ \\
\hline & JUMLAH & $69,90 \%$ \\
\hline
\end{tabular}

Tingkat kesehatan BPRS yang terdiri dari PT BPRS Ampek Angkek Canduang, PT BPRS Carana Kiat Andalas dan PT BPRS Haji Miskin jika ditinjau dari indikator BOPO pada tahun 2014-2018 memperoleh predikat sangat sehat yaitu pada tahun 2014 sebesar 71,84\%, tahun 2015 sebesar 73,60\%, tahun 2016 sebesar 68,61\%, tahun 2017 sebesar 70,99, dan tahun 2018 sebesar 68,49\% ini berarti bahwa bank memiliki efeisiensi operasi yang sangat tinggi dan stabil sehingga memiliki potensi untuk memperoleh 
keuntungan yang tinggi. Jadi, dapat Operasional berada pada predikat disimpulkan bahwa kesehatan Bank sangat sehat yaitu sebesar 69,90\% ini Pembiayaan Rakyat Syariah di berarti bahwa bank memiliki efeisiensi Sumatera Barat periode 2014-2018 jika operasi yang sangat tinggi dan stabil ditinjau dari indikator Beban sehingga memiliki potensi untuk Operasional Terhadap Pendapatan memperoleh keuntungan yang tinggi.

Tabel 13

Kesehatan Bank Pembiayaan Rakyat Syariah Berdasarkan Rasio CAR

\begin{tabular}{|c|c|c|}
\hline Tahun & BPRS & CAR \\
\hline \multirow[t]{4}{*}{2014} & PT BPRS Ampek Angkek Canduang & $25,89 \%$ \\
\hline & PT BPRS Carana Kiat Andalas & $3,05 \%$ \\
\hline & PT Haji Miskin & $42,56 \%$ \\
\hline & Rata-rata & $23,83 \%$ \\
\hline \multirow[t]{4}{*}{2015} & PT BPRS Ampek Angkek Canduang & $15,42 \%$ \\
\hline & PT BPRS Carana Kiat Andalas & $-4,44 \%$ \\
\hline & PT Haji Miskin & $29,35 \%$ \\
\hline & Rata-rata & $13,44 \%$ \\
\hline \multirow[t]{4}{*}{2016} & PT BPRS Ampek Angkek Canduang & $17,85 \%$ \\
\hline & PT BPRS Carana Kiat Andalas & $-6,61 \%$ \\
\hline & PT Haji Miskin & $26,83 \%$ \\
\hline & Rata-rata & $12,69 \%$ \\
\hline \multirow[t]{4}{*}{2017} & PT BPRS Ampek Angkek Canduang & $18,59 \%$ \\
\hline & PT BPRS Carana Kiat Andalas & $14,74 \%$ \\
\hline & PT Haji Miskin & $43,60 \%$ \\
\hline & Rata-rata & $25,64 \%$ \\
\hline \multirow[t]{5}{*}{2018} & PT BPRS Ampek Angkek Canduang & $17,57 \%$ \\
\hline & PT BPRS Carana Kiat Andalas & $19,97 \%$ \\
\hline & PT Haji Miskin & $29,63 \%$ \\
\hline & Rata-rata & $22,39 \%$ \\
\hline & JUMLAH & $19,59 \%$ \\
\hline
\end{tabular}

Sumber : Data Diolah (2020)

Tingkat kesehatan BPRS yang sebesar 23,83\%, tahun 2015 sebesar terdiri dari PT BPRS Ampek Angkek 13,44\%, tahun 2016 sebesar 12,69\%, Canduang, PT BPRS Carana Kiat tahun 2017 sebesar 25,64\%, dan tahun Andalas dan PT BPRS Haji Miskin jika 2018 sebesar 22,39\% ini berarti bahwa ditinjau dari indikator CAR pada tahun bank memiliki modal yang sangat tinggi 2014-2018 memperoleh predikat untuk menutup resiko kerugian dan sangat sehat yaitu pada tahun 2014 melakukan hapus buku akibat 40 | Analisis Penilaian Kesehatan Bank Menggunakan Metode Risk Profile....... 
penurunan kualitas aktiva. Jadi, dapat sangat sehat yaitu sebesar 19,59\% ini disimpulkan bahwa kesehatan Bank berarti bahwa bank memiliki modal Pembiayaan Rakyat Syariah di yang sangat tinggi untuk menutup Sumatera Barat periode 2014-2018 jika resiko kerugian dan melakukan hapus ditinjau dari indikator CAR (Capital buku akibat penurunan kualitas aktiva Adequency Ratio) berada pada predikat

Tabel 14

Penetapan Peringkat Komposit BPRS di Sumatera Barat Berdasarkan Metode RGEC Pada Tahun 2014-2018

\begin{tabular}{|c|c|c|c|c|c|c|c|c|c|c|}
\hline \multirow{2}{*}{ Tahun } & \multirow{2}{*}{ Komponen } & \multirow{2}{*}{ Rasio } & \multirow{2}{*}{ Nilai } & \multicolumn{5}{|c|}{ Peringkat } & \multirow{2}{*}{ Kriteria } & \multirow{2}{*}{ PK } \\
\hline & & & & 1 & 2 & 3 & 4 & 5 & & \\
\hline \multirow[t]{9}{*}{2014} & \multirow{2}{*}{$\begin{array}{c}\text { Risk } \\
\text { Profile }\end{array}$} & NPF & $17,47 \%$ & & & & & $\sqrt{ }$ & TS & \multirow{6}{*}{$\begin{array}{c}\text { PK } 4 \\
\text { Kurang } \\
\text { Sehat }\end{array}$} \\
\hline & & FDR & $272,56 \%$ & & & & & $\sqrt{ }$ & TS & \\
\hline & \multirow[t]{3}{*}{ Earnings } & ROA & $-0,91 \%$ & & & & & $\sqrt{ }$ & TS & \\
\hline & & ROE & $-72,49 \%$ & & & & & $\sqrt{ }$ & TS & \\
\hline & & BOPO & $71,84 \%$ & $\sqrt{ }$ & & & & & SS & \\
\hline & Capital & CAR & $23,83 \%$ & $\sqrt{ }$ & & & & & SS & \\
\hline & \multicolumn{3}{|c|}{ Nilai Komposit } & 10 & & & & 4 & 14 & \\
\hline & \multicolumn{3}{|c|}{ Nilai Komposit Keseluruhan } & & & & & & 30 & \\
\hline & \multicolumn{3}{|c|}{ Perhitungan Nilai Komposit } & & & & & & $46,66 \%$ & \\
\hline \multirow[t]{9}{*}{2015} & \multirow{2}{*}{$\begin{array}{c}\text { Risk } \\
\text { Profile }\end{array}$} & NPF & $25,15 \%$ & & & & & $\sqrt{ }$ & TS & \multirow{9}{*}{$\begin{array}{c}\text { PK4 } \\
\text { Kurang } \\
\text { Sehat }\end{array}$} \\
\hline & & FDR & $204,80 \%$ & & & & & $\sqrt{ }$ & TS & \\
\hline & \multirow[t]{3}{*}{ Earnings } & ROA & $-0,13 \%$ & & & & & $\sqrt{ }$ & TS & \\
\hline & & ROE & $-25,95$ & & & & & $\sqrt{ }$ & TS & \\
\hline & & BOPO & $73,60 \%$ & $\sqrt{ }$ & & & & & SS & \\
\hline & Capital & CAR & $13,44 \%$ & $\sqrt{ }$ & & & & & SS & \\
\hline & \multicolumn{3}{|c|}{ Nilai Komposit } & 10 & & & & 4 & 14 & \\
\hline & \multicolumn{3}{|c|}{ Nilai Komposit Keseluruhan } & & & & & & 30 & \\
\hline & \multicolumn{3}{|c|}{ Perhitungan Nilai Komposit } & & & & & & 46,66 & \\
\hline \multirow[t]{9}{*}{2016} & \multirow[t]{2}{*}{$\begin{array}{c}\text { Risk } \\
\text { Profile }\end{array}$} & NPF & $20,57 \%$ & & & & & $\sqrt{ }$ & TS & \multirow{6}{*}{$\begin{array}{c}\text { PK } 4 \\
\text { Kurang } \\
\text { Sehat }\end{array}$} \\
\hline & & FDR & $221,50 \%$ & & & & & $\sqrt{ }$ & TS & \\
\hline & \multirow[t]{3}{*}{ Earnings } & ROA & $0,91 \%$ & & & & $\sqrt{ }$ & & KS & \\
\hline & & ROE & $6,21 \%$ & & & & $\sqrt{ }$ & & KS & \\
\hline & & BOPO & $68,61 \%$ & $\sqrt{ }$ & & & & & SS & \\
\hline & Capital & CAR & $12,69 \%$ & $\sqrt{ }$ & & & & & SS & \\
\hline & \multicolumn{3}{|c|}{ Nilai Komposit } & 10 & & & 4 & 2 & 16 & \\
\hline & \multicolumn{3}{|c|}{ Nilai Komposit Keseluruhan } & & & & & & 30 & \\
\hline & Perhitunga & lai Kom & & & & & & & $53,33 \%$ & \\
\hline
\end{tabular}




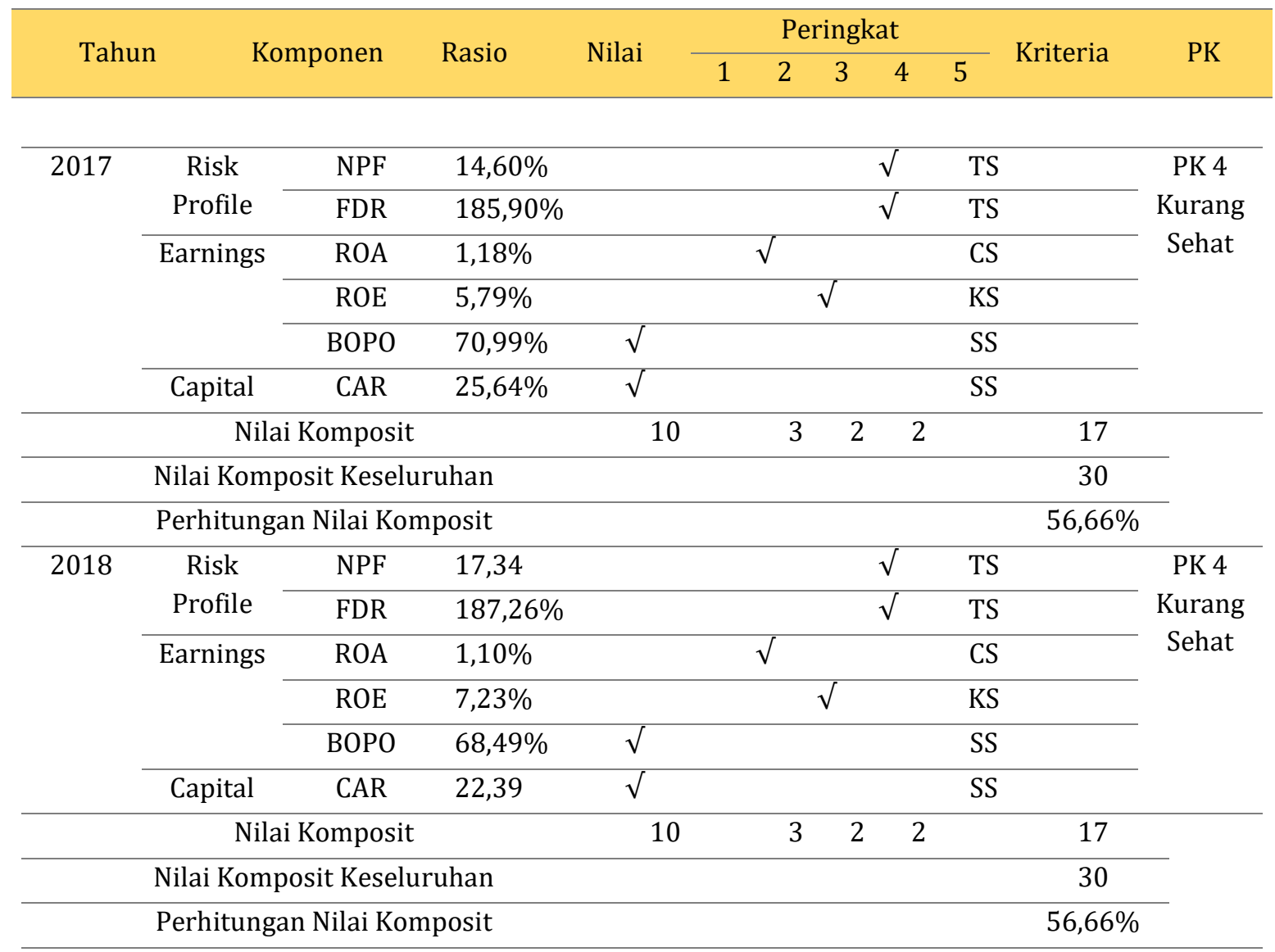

Sumber : Data Diolah (2020)

Hasil analisis tingkat kesehatan Bank Pembiayaan Rakyat Syariah berdasarkan metode Risk Profile, Earning, dan Capital selama tahun 2014-2018 menunjukkan bahwa kesehatan Bank Pembiayaan Rakyat Syariah di Sumatera Barat yang terdapat tiga Bank menjadi sampel peneliti yang terdiri PT BPRS Ampek Angkek Canduang, PT BPRS Carana Kiat Andalas, dan PT BPRS Haji Miskin secara keseluruhan berada pada Peringkat Komposit 4 (PK-4). Dengan rincian bahwa bobot antara 41-60 persen berada pada peringkat kurang sehat sehingga penilaian tingkat kesehatan BPRS di Propinsi Sumbar periode 2014-2018 tersebut masuk dalam peringkat 4 yaitu sebesar $56,66 \%$.

\section{PENUTUP}

Berdasarkan hasil analisis dan pembahasan yang telah diuraikan maka dapat ditarik kesimpulan bahwa penilaian kesehatan Bank Pembiayaan Rakyat Syariah (BPRS) periode 20142018 dengan menggunakan metode RGEC adalah sebagai berikut: Penilaian tingkat kesehatan Bank jika ditinjau dari aspek Risk Profile berada pada predikat tidak sehat. Dapat dibuktikan 42 | Analisis Penilaian Kesehatan Bank Menggunakan Metode Risk Profile....... 
dengan melihat dua indikator yaitu resiko pembiayaan (Non Performing Financing) sebesar 19,02\%, dan resiko likuiditas (Financing To Deposit Ratio) sebesar 272,56\%. Tingkat kesehatan Bank jika ditinjau dari aspek Earning (Rentabilitas) berada pada predikat tidak sehat. Dapat dibuktikan dengan melihat tiga indikator yaitu Return On Assets (ROA) sebesar -0,24\%, Return On Equity (ROE) sebesar -15,84, dan Beban Operasional Terhadap Pendapatan Operasional (BOPO) sebesar 69,90\% Tingkat kesehatan Bank jika ditinjau dari aspek Capital (Permodalan) berada pada predikat sangat sehat. Dapat dibuktikan menggunakan indikator CAR dengan nilainya sebesar 19,59\% Tingkat kesehatan Bank jika ditinjau dari aspek risk profile, earnings, dan capital berada pada predikat kurang sehat (PK-4) sebesar 56,66\%.

\section{DAFTAR KEPUSTAKAAN}

Abdullah, M, M., (2006). Hukum Perbankan dan Perkembangan Bank Syariah di Indonesia. Banjarmasin: Antasari Press.

Antonio, M, S,. (2001). Bank Syariah dari Teori ke Praktek. Jakarta: Gema Insani.

Budisantoso, T., \& Nuritomo. (2015). Bank dan Lembaga Keuangan Lain. Jakarta: Salemba Empat.

Darsono. (2017). Perbankan Syariah Di Indonesia, Kelembagaan dan Kebijakan Serta Tantangan ke Depan. Jakarta: Rajawali Pers.

Dendawijaya, L. (2009). Manajemen Perbankan. Jakarta: Ghalia Indonesia.

Harahap, S,S. (2011). Teori Akuntansi.
Jakarta: Rajawali Pers.

Hasan, Z. (2009). Undang-Undang Perbankan Syariah. Jakarta: PT Raja Grafindo Persada.

Indonesia, B. (2016). Manajemen Kesehatan Bank Berbasis Resiko. Jakarta: Gramedia Pustaka Utama.

Kariyoto. (2017). Analisis Laporan Keuangan. Malang: UB Press.

Kasmir. (2003). Bank dan Lembaga Keuangan Lainnya. Jakarta: PT Raja Grafindo Persada.

Kasmir, \& Jakfar. (2005). Studi Kelayakan Bisnis. Jakarta: Kencana.

Martin, D. J. (1999). Dasar-dasar Manajemen Keuangan. Jakarta: PT Raja Grafindo Persada.

Muhammad. (2005). Manajemen Bank Syariah. Yogyakarta: AMPYKPN.

Oktaviani, S. (2018). Analisis Penilaian Tingkat Kesehatan Bnak Dengan Metode Risk Profile, Good Corporate Governance, Earnings, Capital. JAK (Jurnal Akuntansi) Kajian Ilmiah Akuntansi. Vol.5, No. 2. 2018.

Putri, R. A., \& Marsiwi, D. (2018). Analisis Tingkat Kesehatan Bank Menggunakan Metode CAMEL DAN RGEC (Studi Pada BPR Konvensional Dan BPR Syariah Di Kabupaten Ponorogo).

Rahayu, D., \& Suhendro, S. (2016). Analisis Kesehatan Bank Mandiri dan Bank BCA dengan Metode RGEC tahun 2010-2014. Jurnal Ilmiah Wahana Akuntansi, Vol. 11. No.1. 2016

Sunyoto, D. (2011). Riset Bisnis engan Analisis Jalur SPSS. Jakarta: Gava Media.

Umar, I. (2003). Metode Riset Akuntansi Terapan. Jakarta: Ghalia Indonesia. 
Utami, A. (2012). Jurus Kilat Membuat Laporan Keuangan. Katalog Dalam Terbitan.

Veithrizal, R. (2007). Bank and Financial Institution Manage ment. Jakarta: PT Raja Grafindo Persada.

Yusanto, M. I., \& Kusuma, M. K. W. (2002). Menggagas Bisnis Islam. Jakarta:

Gema Insani 